\title{
ODPOWIEDZIALNOŚĆ PODMIOTÓW ZBIOROWYCH ZA PRZESTĘPSTWA KORUPCYJNE (ASPEKTY MATERIALNOPRAWNE)
}

1. We współczesnym świecie zjawisko korupcji należy do tych problemów i zagrożeń, które wywołują szczególne zaniepokojenie. Ranga problemu jest tym większa, że korupcja dotyka wszystkie sfery życia politycznego, gospodarczego i społecznego. Staje się zjawiskiem ponadnarodowym, o wymiarze globalnym. Niejednokrotnie powiązana jest $\mathrm{z}$ innymi formami przestępczości, w tym w szczególności z przestępczością zorganizowaną i przestępczością gospodarczą oraz związanym z tym ,praniem brudnych pieniędzy”. Społeczność międzynarodowa, dostrzegając zagrożenia, jakie niesie ze sobą zjawisko korupcji, podjęła liczne działania i inicjatywy zmierzające do stworzenia skutecznych instrumentów prawnych zapobiegania i zwalczania korupcji. Warto tu wspomnieć chociażby o przyjętej przez Radę Europy w 1999 r. Prawnokarnej konwencji o korupcji, czy przyjętej przez Zgromadzenie Ogólne Narodów Zjednoczonych w 2003 r. Konwencji przeciwko korupcji, a także Decyzji Ramowej Rady Unii Europejskiej z 2003 r. w sprawie zwalczania korupcji w sektorze prywatnym. Również ustawodawca polski, kierując się względami natury kryminalno-politycznej, a także potrzebą dostosowania unormowań kodeksu karnego do standardów międzynarodowych, dokonał kryminalizacji szerokiej gamy przestępstw korupcyjnych oraz przyjął rozwiązania, które mają za zadanie usprawnienie zwalczania korupcji ${ }^{1}$.

Zob. w szczególności E. Zielińska, Polskie prawo karne a ochrona interesów ekonomicznych Wspólnot Europejskich, Państwo i Prawo 2001, nr 1, s. 47-49; P. Kardas, Odpowiedzialność karna za łapownictwo (rozważania na tle projektowanych nowelizacji kodeksu karnego), Przegląd Sądowy 2002, nr 7-8, s. 3-34; B. Mik, Nowela antykorupcyjna z dnia 13 czerwca 2003 r., Kraków 2003, passim; C. Nowak, Nowe instrumenty prawa międzynarodowego w walce z korupcją a prawo polskie, Państwo i Prawo 2004, nr 3, s. 82-93; tejże, Korupcja w polskim prawie karnym na tle uregulowań międzynarodowych, Warszawa 2008, passim; R.A. Stefański, Przestępstwo korupcji gospodarczej (art. 296a), Prokuratura i Prawo 2004, nr 3, s. 50 i n.; tegoż, Przestępstwo czynnej płatnej protekcji (art. 230a kk.), Prokuratura i Prawo 2004, nr 5, s. 15 i n.; tegoż, Przestępstwo korupcji w sporcie profesjonalnym (art. 296b kk.), Prokuratura i Prawo 2004, nr 2; J. Bojarski, T. Oczkowski, Penalizacja korupcji gospodarczej, Prokuratura i Prawo 2004, nr 4, s. 65; J. Raglewski: Odpowiedzialność karna za korupcję gospodarczą (art. 296a kk.), Prawo Spółek 2005, nr 6, s. 33 i n.; M. Melezini, A. Sakowicz, Nowe regulacje antykorupcyjne a standardy międzynarodowe, (w:) T. Bojarski (red.), Zmiany w polskim prawie karnym po nowelizacjach kk. z 1997 r. Materiały konferencyjne. 20-22 września 2005 r., Lublin 2006, s. 261-284. 
W polu zainteresowań organizacji międzynarodowych, zaangażowanych w stworzenie kompleksowej polityki antykorupcyjnej, obok problematyki odpowiedzialności osób fizycznych za czyny korupcyjne, znalazło się także zagadnienie odpowiedzialności podmiotów zbiorowych.

Wypracowane przez społeczność międzynarodową dokumenty dotyczące odpowiedzialności osób prawnych w zakresie zwalczania, zwłaszcza korupcji ${ }^{2}$, ale także przestępczości zorganizowanej i ,prania brudnych pieniędzy”, stały się następnie impulsem do wprowadzenia koncepcji odpowiedzialności osób prawnych do prawa polskiego. Dokumenty te miały również wpływ na rozwiązania przyjęte przez ustawę z 28.10.2002 r. o odpowiedzialności podmiotów zbiorowych za czyny zabronione pod groźbą kary33. Dzisiaj pozostaje jednak pytanie, czy przyjęta konstrukcja odpowiedzialności podmiotów zbiorowych umożliwia efektywne zwalczanie przestępczości korupcyjnej? Na początek warto przyjrzeć się najbardziej istotnym postanowieniom międzynarodowych aktów prawnych w przedmiocie odpowiedzialności podmiotów zbiorowych za czyny korupcyjne, by następnie odnieść się do rozwiązań polskich.

2. Na szczeblu europejskim jednym z najwcześniejszych dokumentów zawierających ważne rozstrzygnięcia w przedmiocie odpowiedzialności osób prawnych za czyny korupcyjne jest Konwencja o ochronie interesów finansowych Wspólnot Europejskich z dnia 26 lipca 1995 r., a ściślej nawiązujący do niej Drugi Protokół z dnia 19 czerwca 1997 r. ${ }^{4}$ Zobowiązuje on Państwa Członkowskie do ustanowienia w ich wewnętrznym porządku prawnym odpowiedzialności osób prawnych za oszustwo na szkodę interesów finansowych Wspólnot Europejskich, czynną korupcję oraz pranie pieniędzy, jeżeli zostały popełnione w interesie osób prawnych przez jakąkolwiek osobę, działającą indywidualnie bądź wchodzącą w skład pełniącego funkcję kierowniczą organu danej osoby prawnej na podstawie pełnomocnictwa do jej reprezentowania, uprawnienia do podejmowania decyzji w imieniu tej osoby prawnej lub uprawnienia do sprawowania kontroli w obrębie tej osoby prawnej, jak również za udział w popełnieniu lub usiłowaniu popełnienia przez powyższą osobę przestępstwa oszustwa, korupcji czynnej lub prania pieniędzy w charakterze współsprawstwa lub podżegania (art. 3 ust. 1). Protokół nakazuje też podjęcie przez Państwa Członkowskie takich rozstrzygnięć, które zapewnią, że osoby prawne będą pociągane do odpowiedzialności w przypadkach, gdy brak nadzoru lub kon-

Por. S. Waltoś, Odpowiedzialność karna podmiotów zbiorowych - stary problem legislacyjny na nowo, (w:) Prawo. Społeczeństwo. Jednostka. Księga jubileuszowa dedykowana Profesorowi Leszkowi Kubickiemu, red. A. Łopatka, B. Kunicka-Michalska, S. Kiewlicz, Warszawa 2003, s. 389; J. Garstka, Odpowiedzialność karna osób prawnych w prawie międzynarodowym, Prawo i Życie 2000, nr 5, s. 14-20.

3 Dz.U. 2002 r. Nr 197, poz. 1661.

$4 \quad$ Dz.U. WE C 221 z 19.07.2001 r. Ustawa z dnia 22.10.2004 r. Polska ratyfikowała niniejszy Protokół, jak też Konwencję o ochronie interesów finansowych Wspólnot Europejskich (Dz.U. 2004 r. Nr 273, poz. 2699). Ustawa weszła w życie 11.01.2005 r. 
troli przez jedną z wyżej wymienionych osób umożliwił podwładnemu popełnienie wskazanego przestępstwa na rachunek osoby prawnej (art. 3 ust. 2). Ponadto, Protokół przyjmuje tzw. zasadę dwutorowości odpowiedzialności, zgodnie z którą odpowiedzialność osoby prawnej nie wyłącza prowadzenia postępowania karnego przeciwko osobom fizycznym, które brały udział w popełnieniu przestępstwa oszustwa, czynnej korupcji lub prania pieniędzy jako sprawcy, podżegacza lub pomocnika (art. 3 ust. 3 ).

W myśl art. 1 Protokołu ustanawiającego definicję kilku pojęć: „osobą prawną” jest jakikolwiek podmiot mający taki status w obrębie prawa krajowego, z wyjątkiem państwa i innych instytucji publicznych pełniących funkcje władcze oraz międzynarodowych organizacji publicznych. Pojęciem „osoba prawna” nie zostały zatem objęte ułomne osoby prawne, np. na gruncie prawa polskiego spółki jawne czy komandytowe. Z kolei „korupcja czynna” oznacza umyślne działanie kogokolwiek, kto obiecuje albo daje, bezpośrednio lub przez pośrednika, jakiekolwiek korzyści samemu urzędnikowi lub stronie trzeciej dla urzędnika, dla podjęcia albo powstrzymania się przez urzędnika od działań należących do jego obowiązków w sposób narażający lub mogący narazić interesy finansowe Wspólnot Europejskich5

Należy zauważyć, że omawiany dokument nie określa charakteru odpowiedzialności osób prawnych, pozostawiając tym samym państwom członkowskim wybór modelu tej odpowiedzialności, w szczególności, czy ma to być odpowiedzialność karna, cywilna czy administracyjna. Ważne jest to, by w ramach odpowiedzialności osób prawnych zostały wprowadzone sankcje natury finansowej, które jednak mają charakter represyjny.

Zgodnie z art. 4 Protokołu, osoby prawne mają podlegać sankcjom skutecznym, proporcjonalnym i odstręczającym, włączając $\mathrm{w}$ to karę grzywny lub inną karę pieniężną. Ponadto, mogą też być ustanowione inne sankcje, takie jak w szczególności:

- odebranie uprawnień do korzystania ze świadczeń lub pomocy publicznej,

- terminowy lub stały zakaz prowadzenia działalności gospodarczej,

- oddanie pod nadzór sądu,

- sądowy nakaz rozwiązania osoby prawnej.

Katalog środków jest otwarty. Również w tym zakresie dokument pozostawia państwom członkowskim daleko idącą swobodę w wyborze sankcji stosowanych 
wobec osób prawnych za dokonane w ich interesie oszustwa, czynnej korupcji lub prania pieniędzy ${ }^{6}$.

3. Postanowienia w przedmiocie odpowiedzialności osób prawnych za czyny korupcyjne zawiera też Konwencja OECD o zwalczaniu przekupstwa zagranicznych funkcjonariuszy publicznych w międzynarodowych transakcjach handlowych z dnia 17.12.1997 r. ${ }^{7}$ W preambule Konwencji Państwa-Strony uznały, że przekupstwo jest szeroko rozpowszechnionym zjawiskiem w międzynarodowych transakcjach handlowych, włączając handel i inwestycje, które powoduje poważne zaniepokojenie moralne i polityczne, podważając dobre sprawowanie rządów oraz rozwój gospodarczy i wypaczając warunki międzynarodowej konkurencji. Strony uznały także, że wszystkie państwa „dzielą odpowiedzialność” za zwalczanie tego zjawiska. Traktując problem jako niezwykle doniosły, Konwencja przedstawiła zapisy na mocy których nałożyła na Państwa-Strony obowiązek ustanowienia obok odpowiedzialności osób fizycznych także odpowiedzialność podmiotów zbiorowych za przekupstwo zagranicznego funkcjonariusza publicznego (art. 2).

Należy zauważyć, że treść przepisów Konwencji ma charakter bardzo ogólny. Przepis art. 3 pozostawia Stronom swobodę w określaniu rodzaju odpowiedzialności i jej przesłanek. Jednakże z przepisu art. 3 ust. 2 Konwencji wynika pewna preferencja odpowiedzialności karnej osób prawnych. Stanowi on bowiem, że „W przypadku gdy w systemie prawnym Strony osoby prawne nie podlegają odpowiedzialności karnej, Strona ta zapewni, że osoby prawne podlegać będą za przekupstwo zagranicznego funkcjonariusza publicznego skutecznym, proporcjonalnym oraz odstręczającym sankcjom innym niż karne, włącznie z sankcjami pieniężnymi”. Dodać trzeba, że w zakresie kar Konwencja postanawia, iż mają to być kary porównywalne do kar, jakie są stosowane w prawie wewnętrznym za przekupstwo własnych funkcjonariuszy publicznych (art. 3 ust. 1).

Ponadto Konwencja nakazuje Stronom podjęcie niezbędnych działań w celu zagwarantowania, że łapówka i korzyść majątkowa wskutek przekupstwa zagranicznego funkcjonariusza publicznego lub mienie, którego wartość odpowiada takim korzyściom, podlegać będą zajęciu i konfiskacie, albo zamiennie z przepadkiem stosowane będą kary pieniężne o porównywalnym skutku (art. 3 ust. 3). Dodatkowo w art. 4 ust. 3 zobowiązuje się strony do rozważenia możliwości nałożenia na osoby

6 Por. J. Garstka, Odpowiedzialność podmiotów zbiorowych w prawie międzynarodowym, Prawo i Życie 2000, nr 5, s. 14 i n.; O. Górniok, Komentarz do konwencji o ochronie interesów finansowych Wspólnot Europejskich wraz protokołami dodatkowymi, (w:) Prawo Wspólnot Europejskich a prawo polskie. Dokumenty karne, pod red. E. Zielińskiej, Warszawa 2000, s. 276.

$7 \quad$ Konwencja została podpisana przez Polskę i ogłoszona 3.11.2000 r. Weszła w życie 4.02.2001 r. (Dz.U. 2001 r. $\mathrm{Nr} 23$, poz. 264). 
prawne także sankcji cywilnych lub administracyjnych za przekupstwo zagranicznego funkcjonariusza publicznego ${ }^{8}$.

4. Bardzo wcześnie problem korupcji stał się przedmiotem zainteresowania Rady Europy. Pierwsze wypracowane dokumenty (zalecenia czy rezolucje) miały charakter tzw. „soft law”. . Dopiero przyjęta przez Radę Europy dnia 27.01.1999 r. Prawnokarna konwencja o korupcji była dokumentem zawierającym zobowiązania w zakresie dostosowania prawa karnego do wypracowanych standardów ${ }^{10}$. Miała też znaczący wpływ na rozwiązania przyjęte w prawie polskim w zakresie przepisów antykorupcyjnych.

Konwencja, ustanawiając szeroki zakres przestępstw korupcyjnych, za które należy pociągać do odpowiedzialności osoby fizyczne, wprowadza także zobowiązanie dotyczące odpowiedzialności osób prawnych. Artykuł 18 ust. 1 stanowi, że każda Strona przyjmie takie środki ustawodawcze i inne, jakie mogą być konieczne do zapewnienia, by osoby prawne mogły ponosić odpowiedzialność za przestępstwa czynnego przekupstwa, handlu wpływami i prania pieniędzy, określone zgodnie z konwencją, popełnione na ich korzyść przez działającą indywidualnie, albo jako część organu osoby prawnej, jakąkolwiek osobę fizyczną, która posiada wiodącą rolę w ramach tej osoby prawnej, na podstawie:

- umocowania do reprezentowania tej osoby prawnej, lub

- uprawnienia do podejmowania decyzji w imieniu tej osoby prawnej, lub

- uprawnienia do sprawowania kontroli w obrębie tej osoby prawnej, jak również za udział takich osób fizycznych we wskazanych wyżej przestępstwach, jako współsprawców lub podżegaczy.

Dodatkowo, osoba prawna będzie ponosić odpowiedzialność, jeśli brak nadzoru lub kontroli ze strony osoby fizycznej wymienionej wyżej umożliwił podporządkowanej jej osobie fizycznej popełnienie jednego z przedmiotowych przestępstw na korzyść tej osoby prawnej (art. 18 ust. 2). Odpowiedzialność osoby prawnej nie wyłącza jednak postępowania karnego przeciwko osobom, które są sprawcami, podżegaczami lub współsprawcami wymienionych przestępstw (art. 18 ust. 3). Stosownie do art. 19 ust. 2 Konwencji osoby prawne mają podlegać skutecznym, proporcjonalnym i zniechęcającym sankcjom karnym lub innym, w tym sankcjom pieniężnym.

Por. J. Garstka, Komentarz do Konwencji z dnia 17.12.1997 r. o zwalczaniu przestępczości zorganizowanej funkcjonariuszy w międzynarodowych transakcjach handlowych, (w:) Prawo Wspólnot Europejskich a prawo polskie. Dokumenty karne, t. 6, część II. Wybór tekstów z komentarzem, Warszawa 2005, s. 306 i n.

Były to: Program Działań przeciwko korupcji (1996 r.), Rezolucja (97) 24 w sprawie „20 Zasad Przewodnich w walce z korupcja”, Rezolucja 98 (7) w sprawie utworzenia „Grupy Państw przeciwko Korupcji - GRECO”. Należy nadmienić, że od 20.05.1999 r. Polska jest członkiem Grupy Państw przeciwko Korupcji. Zob. M. Melezini, A. Sakowicz, Nowe regulacje..., s. 264. 
5. O odpowiedzialności osób prawnych za przestępstwa jest także mowa w Konwencji Narodów Zjednoczonych przeciwko międzynarodowej przestępczości zorganizowanej z dnia 15.11.2000 r. ${ }^{11}$. Instrument ten przewiduje obowiązek ustanowienia odpowiedzialności osób prawnych za udział w poważnych przestępstwach, w które zaangażowana jest zorganizowana grupa oraz za takie przestępstwa, jak udział w zorganizowanej grupie przestępczej, pranie dochodów z przestępstwa, przekupstwo oraz wymienione w Konwencji przestępstwa przeciwko wymiarowi sprawiedliwości. W art. 10 ust. 2 i 3 wskazuje się, że odpowiedzialność osób prawnych może mieć charakter karny, cywilny lub administracyjny, w zależności od zasad prawnych obowiązujących w danym państwie, przy czym tego rodzaju odpowiedzialność nie przesądza odpowiedzialności osób fizycznych, które popełniły przestępstwo. Ponadto Konwencja wymaga, by każde państwo zapewniło, że osoby prawne będą podlegały skutecznym, proporcjonalnym oraz odstraszającym sankcjom karnym lub pozakarnym, w tym sankcjom finansowym (art. 10 ust. 4).

6. Bardzo zbliżoną postać do wskazanej powyżej mają zobowiązania dotyczące wprowadzenia odpowiedzialności osób prawnych za czyny korupcyjne, wynikające z przyjętej dnia 31.10.2003 r. Konwencji Narodów Zjednoczonych przeciwko korupcji ${ }^{12}$. Jedyna różnica zapisów art. 26 Konwencji wiąże się z wymogiem ustanowienia odpowiedzialności osób prawnych za udział w szerszej gamie przestępstw, które zostały określone w dokumencie. Są to: sprzedajność i przekupstwo krajowych i zagranicznych funkcjonariuszy publicznych (art. 15 i 16) oraz funkcjonariuszy międzynarodowych organizacji publicznych (art. 16), sprzeniewierzenie i wyłudzenie mienia przez funkcjonariusza publicznego (art. 17), płatna protekcja (art. 18), nadużycie władzy (19), bezpodstawne wzbogacenie funkcjonariusza publicznego (art. 20), przekupstwo w sektorze prywatnym (art. 21), sprzeniewierzenie mienia w sektorze prywatnym (art. 22), pranie pieniędzy (art. 23), paserstwo (art. 24) oraz wywieranie bezprawnych nacisków na sąd i świadków (art. 25).

Warto wspomnieć, iż Konwencja NZ, dążąc do kompleksowego ujęcia problemu zapobiegania i zwalczania korupcji, wytycza szeroki zakres jej stosowania, określony w art. 3 jako zapobieganie, dochodzenie i ściganie korupcji, a także zamrażanie, zatrzymanie, konfiskatę oraz zwrot dochodów pochodzących z przestępstw ustanowionych w Konwencji ${ }^{13}$.

7. Ważnym instrumentem, który wytyczył nowe kierunki polityki antykorupcyjnej na szczeblu europejskim, było Wspólne Działanie z dnia 22.12.1998 r., przyjęte przez Radę Unii Europejskiej, w sprawie korupcji w sektorze prywatnym ${ }^{14}$. Akt

\footnotetext{
11 Polska przystapiła do Konwencji w 2001 r. Zob. Ustawa z dnia 19.07.2001 r. o ratyfikowaniu Konwencji Narodów Zjednoczonych przeciwko międzynarodowej przestępczości zorganizowanej, Dz.U. Nr 90, poz. 994. Polska podpisała Konwencje 10.12.2003 r.

Por. C. Nowak, Nowe instrumenty..., s. 82-87; M. Melezini, A. Sakowicz, Nowe regulacje..., s. 266-267. Dz.U. WE L 192 z 31.12.1998 r.
} 
ten nie miał jednak charakteru wiążącego, ale z czasem stał się podstawą do wydania Decyzji Ramowej, która jest instrumentem dalej idącym i wiąże państwa członkowskie co do celu, który ma być osiągnięty.

Przyjęta dnia 22 lipca 2003 r. przez Radę UE Decyzja Ramowa w sprawie zwalczania korupcji w sektorze prywatnym ${ }^{15}$, nawiązując do Wspólnego Działania, stawia sobie za cel pogłębienie walki z korupcją w sektorze prywatnym, w tym rozciągnięcie odpowiedzialności karnej za korupcję czynną i bierną także na osoby prawne.

Na mocy art. 5 ust. 1 Decyzji Ramowej Państwa Członkowskie UE zobowiązują się do ustanowienia odpowiedzialności osób prawnych za przestępstwo czynnej i biernej korupcji w sektorze prywatnym, popełnione na korzyść osoby prawnej przez osobę fizyczną, działającą indywidualnie albo wchodzącą w skład organu osoby prawnej, która ma w niej pozycję kierowniczą, w oparciu o:

- prawo do reprezentowania osoby prawnej,

- uprawnienia do podejmowania decyzji w imieniu osoby prawnej, lub

- uprawnienia do sprawowania kontroli w strukturach osoby prawnej.

Dodatkowo Decyzja Ramowa nakłada na Państwa Członkowskie obowiązek zapewnienia, by osoby prawne były pociągane do odpowiedzialności w przypadku, gdy osoba fizyczna, zajmująca pozycję kierowniczą, dopuściła się uchybienia w nadzorze lub kontroli, umożliwiając popełnienie przestępstwa korupcji w sektorze prywatnym przez swego podwładnego na korzyść danej osoby prawnej (art. 5 ust. 2).

Omawiany instrument prawny definiuje „osobę prawną”, podobnie jak Drugi Protokół z 1997 r. do Konwencji o ochronie interesów finansowych Wspólnot Europejskich, jako podmiot posiadający taki status zgodnie $\mathrm{z}$ właściwym prawem krajowym, z wyjątkiem państw lub innych organów publicznych, działających w charakterze władz państwowych oraz międzynarodowych organizacji publicznych (art. 1).

Należy podkreślić, że przepisy Decyzji Ramowej nie przesądzają o charakterze odpowiedzialności osób prawnych, pozostawiając Państwom Członkowskim wybór rodzaju odpowiedzialności (karna, cywilna czy administracyjna). Rozwiązania w tym przedmiocie zasadniczo pokrywają się z konstrukcjami innych dokumentów międzynarodowych.

Ponadto Decyzja Ramowa w art. 5 ust. 3 ustanawia tzw. zasadę dwutorowości odpowiedzialności, zgodnie z którą odpowiedzialność osoby prawnej nie wyklucza postępowania karnego przeciwko osobom fizycznym, które brały udział w popeł- 
nieniu przestępstwa czynnej i biernej korupcji w sektorze prywatnym jako sprawcy, podżegacze lub pomocnicy. Również w tym zakresie przyjęte zapisy nie odbiegają od postanowień wcześniejszych dokumentów.

W odniesieniu do sankcji wobec osób prawnych, Decyzja Ramowa przewiduje sankcje stosowane wobec osób prawnych za czyny korupcji w sektorze prywatnym popełnione w warunkach odpowiedzialności zobiektywizowanej (art. 5 ust. 1) oraz sankcje stosowane wobec osób prawnych, którym można przypisać winę (art. 5 ust. 2). W pierwszym przypadku (art. 6 ust. 1) osoba prawna ma podlegać sankcjom skutecznym, proporcjonalnym i odstraszającym, obejmującym karę grzywny lub inną karę, bądź takie sankcje, jak:

- pozbawienie prawa do korzystania ze świadczeń publicznych lub pomocy publicznej,

- czasowy lub stały zakaz prowadzenia działalności gospodarczej,

- przekazanie pod nadzór sądowy,

- sądowe orzeczenie o likwidacji.

W drugim przypadku (art. 6 ust. 2) - osoba prawna ma podlegać karom lub środkom, które są skuteczne, proporcjonalne i odstraszające.

Należy zwrócić uwagę, że Decyzja Ramowa wyznaczyła konkretny termin implementacji jej postanowień. Zgodnie z art. 9 ust. 1 Państwa Członkowskie miały czas do przyjęcia regulacji dostosowawczych do dnia 22 lipca 2005 r. Do tej daty Państwa Członkowskie miały też przekazać Sekretarzowi Generalnemu Rady oraz Komisji tekst przepisów transponujących postanowienia decyzji do prawa wewnętrznego. Z kolei Rada UE do dnia 22 października 2005 r. miała dokonać oceny stopnia realizacji przepisów decyzji ramowej (art. 9 ust. 2).

8. Z przytoczonych przepisów instrumentów międzynarodowych wynika, że obecnie odpowiedzialność osób prawnych za czyny korupcyjne stała się międzynarodowym standardem. Prawo polskie do 2002 r. nie przewidywało odpowiedzialności osób prawnych za czyny zabronione popełnione na ich korzyść przez osobę fizyczną. Zrodziło to potrzebę podjęcia stosowanych działań przez ustawodawcę polskiego, które doprowadziłyby do wprowadzenia do polskiego systemu prawnego odpowiedzialności osób prawnych.

Dnia 28 października 2002 r. uchwalono ustawę o odpowiedzialności podmiotów zbiorowych za czyny zabronione pod groźbą kary, która obowiązuje od 22 listopada 2003 r. ${ }^{16}$ Od początku rozwiązania przyjęte w ustawie budziły rozliczne kontrowersje, poczynając od charakteru odpowiedzialności podmiotów zbiorowych, 
kaskadowości polskiej konstrukcji odpowiedzialności podmiotów zbiorowych, konstrukcji winy czy też rodzajów środków represyjnych stosowanych wobec podmiotów zbiorowych.

9. Naprzód należy zauważyć, że w doktrynie nie ma zgodności co do charakteru odpowiedzialności podmiotów zbiorowych. Mówi się o odpowiedzialności karno-administracyjnej ${ }^{17}$, quasi-karnej ${ }^{18}$ czy też nowej szczególnej odpowiedzialności karnej $^{19}$. Jednocześnie w piśmiennictwie podkreśla się, że sam charakter podmiotu podlegającego odpowiedzialności na podstawie ustawy z 28 października $2002 \mathrm{r}$. nie wyklucza jej karnoprawnego charakteru ${ }^{20}$, a wymierzane na podstawie ustawy sankcje względem podmiotów zbiorowych wskazują na karny charakter tej odpowiedzialności ${ }^{21}$. Autorzy takiego poglądu wskazują na związki u.o.p.z. z prawem karnym, o czym świadczy wymóg odpowiedniego stosowania przepisów kodeksu postępowania karnego (art. 22) i kodeksu karnego wykonawczego (art. 26), przeniesienie na jej grunt niektórych instytucji znanych prawu karnemu (np. recydywa, przedawnienie karalności, przedawnienie wykonania kary) czy też umieszczenie w Krajowym Rejestrze Karnym informacji o podmiotach zbiorowych, wobec których orzeczono karę pieniężną, przepadek, zakaz lub podanie wyroku do publicznej wiadomości. Równocześnie zauważa się w literaturze, że przepisy u.o.p.z. przewidują odpowiedzialność represyjną̧2 , bądź nie przewidują odpowiedzialności sensu stricto karnej. Autorzy ostatniego poglądu stoją na stanowisku, że jest to odpowiedzialność różna od odpowiedzialności karnej. Stanowi wyraz legitymacji ustawodawcy ,do represjonowania bezprawia z tytułu samej niesubordynacji wobec porządku prawnego, w oderwaniu od warunku czynu, winy i podziałów na klasyczne rodzaje odpowiedzialności oraz poza ustawami karnymi (tzw. obiektywna koncepcja odpowiedzialności)"’23. Można także spotkać stanowisko wskazujące, że analizowana odpowiedzialność jest odpowiedzialnością karną ${ }^{24}$. nione pod groźbą kary, Palestra 2004, nr 1-2, s. 84-86.

M. Czyżak, Karnoadministracyjne, karnoskarbowe i quasi-karne formy odpowiedzialności podmiotów zbiorowych, Wojskowy Przegląd Prawniczy 2004, nr 1, s. 38.

J. Skupiński, Problemy kryminalnopolityczne związane z promulgowaniem ustawy z dnia 28 października $200 \mathrm{r}$. o odpowiedzialności podmiotów zbiorowych za czyny zabronione pod groźbą kary, (w:) Odpowiedzialność karna podmiotów zbiorowych. Konferencja Jastrzębia Góra, 12-14 października 2003 r., Apelacja Gdańska - Wydanie Specjalne 2003, nr 3, s. 47-48.

20 Por. B. Namysłowska-Gabrysiak, Ustawa o odpowiedzialności podmiotów zbiorowych za czyny zabronione pod groźbą kary. Komentarz, Kraków 2004, s. 71; B. Nita, Model odpowiedzialności podmiotów zbiorowych za czyny zabronione pod groźbą kary, Państwo i Prawo 2003, nr 6, s. 18; S. Waltoś, Odpowiedzialność karna podmiotów zbiorowych - stary problem legislacyjny na nowo, (w:) Prawo, społeczeństwo, jednostka. Księga jubileuszowa dedykowana Profesorowi Leszkowi Kubickiemu, Warszawa 2003, s. 396-406 Por. A. Bartosiewicz, R. Kubacki, Ustawodawca nad wyraz lakoniczny, Rzeczpospolita z 20 sierpnia 2003 r. Zob. np. B. Nita, Model odpowiedzialności podmiotów zbiorowych..., s. 18 i n.

23 B. Mik, Charakter prawny odpowiedzialności podmiotów zbiorowych w świetle ustawy z dnia 28 października 2002 r., Przegląd Sądowy 2003, nr 7-8, s. 67; zob. też M. Filar (red.), Z. Kwaśniewski, D. Kala, Komentarz do ustawy o odpowiedzialności podmiotów zbiorowych za czyny zabronione pod groźbą kary, Toruń 2003, s. 4142.

24 S. Waltoś, Odpowiedzialność karna podmiotów zbiorowych - stary problem legislacyjny na nowo, (w:) Prawo, społeczeństwo, jednostka. Księga jubileuszowa dedykowana Prof. Leszkowi Kubickiemu, pod red. A. Łopatka, 
Problematyka modelu odpowiedzialności podmiotów zbiorowych doczekała się również orzeczenia Trybunału Konstytucyjnego. W uzasadnieniu wyroku z dnia 3 listopada 2004 r., sygn. akt K 18/03, Trybunał wskazał, że model odpowiedzialności podmiotów zbiorowych nie ma charakteru odpowiedzialności karnej sensu stricto, podkreślając zarazem, iż uregulowania u.o.p.z. określają odpowiedzialność o charakterze represyjnym. Nie roztrząsają bliżej tego poglądu, który jest skądinąd trafny. Wątpliwości budzi sposób argumentacji, która doprowadziła do takiej konkluzji. Otóż, Trybunał Konstytucyjny wskazał, że przyjęty w u.o.p.z. model odpowiedzialności nie może być uznany za odpowiedzialność karną sensu stricte, bowiem ,jej podstawą materialną nie jest wyczerpanie przez podmiot odpowiedzialności swym czynem ustawowych znamion określonej normy prawa karnego typizującej przestępstwo lub przestępstwo skarbowe. Nie ma więc ona charakteru pierwotnego i samoistnego, lecz charakter wtórny i pochodny. Jej materialną podstawą jest prawomocne skazanie (lub inne orzeczenie, o którym mowa w art. 4 ustawy) osoby fizycznej wymienionej w art. 3 u.o.p.z. za przestępstwo lub przestępstwo skarbowe wymienione $\mathrm{w}$ art. 16 u.o.p.z.. Brak tu więc typowego dla prawa karnego wymogu naruszenia przez podmiot odpowiedzialności karnej tzw. normy sankcjonowanej. Prawnokarną normę sankcjonowaną typizującą określone przestępstwo narusza tu nie podmiot zbiorowy, lecz osoba fizyczna, o której mowa w art. 3 ustawy".

Wydaje się, że kaskadowość przyjętej konstrukcji nie może rzutować na charakter odpowiedzialności podmiotów zbiorowych. Wynika on bowiem z charakteru środków, które mogą być orzekane wobec podmiotu zbiorowego, a te ewidentnie mają charakter represyjny. Świadczą chociażby o tym przesłanki tej odpowiedzialności, a przede wszystkim cel i funkcja orzekanych wobec podmiotów zbiorowych kar. Zdaniem Trybunału, pominięcie przez ustawodawcę w tytule ustawy i jej treści bezpośredniego wskazania na „odpowiedzialność karną” podmiotów zbiorowych można tłumaczyć względami legislacyjnymi, bowiem użycie tego zwrotu obligowałoby do stosowania wprost części ogólnej kodeksu karnego ze względu na art. 116 kk., który stanowi, iż „Przepisy części ogólnej tego kodeksu stosuje się do innych ustaw przewidujących odpowiedzialność karną, chyba że ustawy te wyraźnie wyłączają ich zastosowanie". Nie powinno być zatem wątpliwości, że odpowiedzialność podmiotów zbiorowych na płaszczyźnie konstytucyjnej jest odpowiedzialnością represyjną. Z pewnością ustawowe znaczenie pojęcia „odpowiedzialność karna” nie może rzutować na treść tego samego pojęcia użytego w Konstytucji RP ${ }^{25}$. Dzieje się tak nie tylko dlatego, że konstytucyjne znaczenie tego pojęcia nie może być ustalane poprzez odwołanie się do obowiązującego ustawodawstwa, co podważałoby rangę

B. Kunicka-Michalska, S. Kiewlicz, Warszawa 2003, s. 405-40; tegoż, Wprowadzenie do problematyki odpowiedzialności podmiotów zbiorowych, (w:) Odpowiedzialność karna podmiotów zbiorowych. Konferencja Jastrzębia Góra, 12-14 października 2003 r., Apelacja Gdańska - Wydanie Specjalne 2003, nr 3; tegoż, O odpowiedzialności karnej podmiotów zbiorowych, Edukacja Prawnicza 2003, nr 12, s. 30. 
normy konstytucyjnej, ale również i z tego powodu, że regulacja art. 42 Konstytucji RP utraciłaby swoje znaczenie gwarancyjne. Mając to na względzie, należy przyjąć, że zakres stosowania art. 42 Konstytucji obejmuje nie tylko odpowiedzialność karną w ścisłym tego słowa znaczeniu, a więc odpowiedzialność za przestępstwa, ale również inne formy odpowiedzialności prawnej związanej z wymierzaniem kar wobec jednostki ${ }^{26}$. Podobnie więc jak w wypadku odpowiedzialności dyscyplinarnej czy odpowiedzialności za wykroczenia, konstytucyjne standardy odnoszone do prawa karnego (represyjnego) mają zastosowanie także do odpowiedzialności podmiotów zbiorowych, przewidzianej w zakwestionowanej ustawie. W szczególności przepisy ustawy podlegają ocenie z punktu widzenia zasady dostatecznej określoności prawa represyjnego, którą, poza art. 42 Konstytucji, można wywodzić z zasady ochrony zaufania do państwa i stanowionego w tym państwie prawa (art. 2 Konstytucji RP), a także z punktu widzenia pozostałych gwarancji konstytucyjnych, ustanowionych w art. 42 Konstytucji.

Na koniec tego wątku warto podnieść, że przygotowany przez Komisję Kodyfikacyjną pod przewodnictwem prof. S. Waltosia projekt kompleksowego uregulowania kwestii odpowiedzialności podmiotów zbiorowych zakładał włączenie uregulowania w tym zakresie do kodeksu karnego, a tym samym jednoznacznie przesądzał o charakterze analizowanej tu odpowiedzialności ${ }^{27}$. Projektodawcy stanęli na stanowisku, że sankcje stosowane wobec podmiotu zbiorowego muszą mieć charakter penalny; powinny oddziaływać na te podmioty kolektywne, które dopuściły się czynów zabronionych, jak również na inne.

10. Analiza tytułowego problemu nie może nastąpić bez sygnalizacyjnego odniesienia się do ujęcia podmiotu zbiorowego oraz przesłanek jego odpowiedzialności. Zgodnie z obwiązującym art. 2 ust. 1 u.o.p.z., podmiotem zbiorowym jest osoba prawna oraz jednostka organizacyjna niemająca osobowości prawnej, której odrębne przepisy przyznają zdolność prawną, z wyłączeniem Skarbu Państwa, jednostek samorządu terytorialnego i ich związków. Ponadto art. 2 ust. 2 u.o.p.z. dodaje, że podmiotem zbiorowym jest również spółka handlowa z udziałem Skarbu Państwa, jednostki samorządu terytorialnego lub związki takich jednostek, spółka kapitałowa w organizacji, podmiot w stanie likwidacji oraz przedsiębiorca niebędący osobą fizyczną, a także zagraniczna jednostka organizacyjna.

Wypada zatem uszczegółowić definicję podmiotu zbiorowego. Obejmie ona osoby prawne, którym przepisy przyznają osobowość prawną (zob. art. 33 kc.), jak również jednostki organizacyjne niemające osobowości prawnej, którym odrębne przepisy przyznają zdolność prawną. W szczególności wskazać tu należy na osobo-

26

27 nr 9, s. 3-16; D. Haber, Materialnoprawne aspekty odpowiedzialności podmiotów zbiorowych w polskim prawie karnym, Toruń 2008 , s. 148-160. 
we spółki handlowe w rozumieniu Kodeksu spółek handlowych (tj. spółka jawna, partnerska, komandytowa oraz komandytowo-akcyjna), które, zgodnie z art. 8 § 1 ksh., mogą we własnym imieniu nabywać prawa, w tym własność nieruchomości i inne prawa rzeczowe, zaciągać zobowiązania, pozywać i być pozywane, ponadto są to także wspólnoty mieszkaniowe oraz organizacje społeczne dopuszczone do działania na podstawie obowiązujących przepisów art. $64 \S 2$ kpc.).

Warto dodać, że w obecnym brzemieniu nadanym nowelą z dnia 28 lipca 2005 r. przepis art. 2 u.o.p.z. nie obejmuje spółki cywilnej. Wynika to z faktu, że w świetle przepisów kodeksu cywilnego i orzecznictwa spółka cywilna jest $\mathrm{w}$ istocie stosunkiem zobowiązaniowym łączącym jej wspólników (art. 860 kc.). Trudno więc kwalifikować taki stosunek obligacyjny jako jednostkę organizacyjną tworzącą odrębny od wspólników podmiot praw i obowiązków ${ }^{28}$. Przykładowo w postanowieniu z 11 marca 1998 r..$^{29}$ Sąd Najwyższy scharakteryzował spółkę cywilną jako spółkę osobową, organizację wspólników, związanych wspólnością w celu gospodarczym i współwłasnością łączną w odniesieniu do zgromadzonego majątku spółki. Podmiotowość prawna przysługuje w niej tylko wspólnikom. Nie jest zatem uzasadnione przeciwstawianie spółki jej wspólnikom i zajmowanie stanowiska, że proces przeciwko spółkom cywilnym nie jest procesem wspólników. Poza tym, przyjęcie możliwości prowadzenia postępowania przeciwko spółce cywilnej urealnia możliwość naruszenia zasady ne bis in idem, która należy do fundamentalnych zasad prawa karnego, a zatem jest elementem zasady państwa prawnego. Wszelkie odstępstwa od tej zasady, w szczególności zaś stworzenie organowi władzy publicznej kompetencji do dwukrotnego zastosowania środka represyjnego wobec tego samego podmiotu za ten sam czyn, stanowiłoby naruszenie regulacji konstytucyjnych ${ }^{30}$. Słusznie więc Trybunał Konstytucyjny wyłączył spod zakresu ,jednostek organizacyjnych niemających osobowości prawnej”, o których była mowa w art. 2 ust. 1 u.o.p.z. (sprzed nowelizacji) ${ }^{31}$. Obecnie treść tego przepisu wyraźnie wskazuje, że chodzi o ,jednostki organizacyjne niemające osobowości prawnej, którym odrębne przepisy przyznają zdolność prawną".

11. Przechodząc dalej, należy zatrzymać się przy przesłankach odpowiedzialności podmiotów zbiorowych, które zostały określone w art. 3-5 u.o.p.z. Przesłanki te wskazują na przyjęcie kaskadowego modelu odpowiedzialności podmiotów zbiorowych. Zanim to jednak nastąpi, należy wyraźnie podkreślić, że zarówno art. 3 ust. 2 Drugiego Protokołu, jak i art. 5 ust. 3 Decyzji Ramowej w sprawie zwalcza-

Por. Z. Kwaśniewski, (w:) M. Filar (red.), Z. Kwaśniewski, D. Kala, Komentarz do ustawy o odpowiedzialności podmiotów zbiorowych za czyny zabronione pod groźbą kary, Toruń 2003, s. 45; B. Namysłowska-Gabrysiak, Ustawa o odpowiedzialności podmiotów..., s. 88-89

29 Postanowienie SN z 11 marca 1998 r. sygn. akt III CZP 2/98, Prokuratura i Prawo-dodatek 1998, nr 6.

30 Wyrok TK z 3 listopada 2004 r., sygn. akt K 18/03, OTK-A 2004, nr 10, poz. 103.

31 Zob. szerzej B. Draniewicz, Spółka cywilna a odpowiedzialność podmiotów zbiorowych, Prawo Spółek 2005, nr 7-8, s. 89. 
nia korupcji w sektorze prywatnym nie wyłączają prowadzenia postępowania karnego przeciwko osobom fizycznym będącym sprawcami, podżegaczami lub pomocnikami przestępstwa oszustwa, czynnej korupcji lub prania dochodów (Protokół II) oraz czynnej lub biernej korupcji w sektorze prywatnym (Decyzji Ramowej w sprawie zwalczania korupcji w sektorze prywatnym). Wyrażona w powyższych unormowaniach zasada kumulacji postępowania nie znalazła odzwierciedlenia w polskiej u.o.p.z., która przyjęła model dwuetapowy ${ }^{32}$.

Po pierwsze zauważyć należy, że polski ustawodawca uznał, iż podmiot zbiorowy będzie mógł podlegać odpowiedzialności za czyn zabroniony, którym jest zachowanie osoby fizycznej:

1) działającej w imieniu lub $w$ interesie podmiotu zbiorowego w ramach uprawnienia lub obowiązku do jego reprezentowania, podejmowania w jego imieniu decyzji lub wykonywania kontroli wewnętrznej albo przy przekroczeniu tego uprawnienia lub niedopełnieniu tego obowiązku,

2) dopuszczonej do działania w wyniku przekroczenia uprawnień lub niedopełnienia obowiązków przez osobę, o której mowa w pkt 1,

3) działającej w imieniu lub w interesie podmiotu zbiorowego, za zgodą lub wiedzą osoby, o której mowa w pkt 1.

- jeżeli zachowanie to przyniosło lub mogło przynieść podmiotowi zbiorowemu korzyść, chociażby niemajątkową (art. 3). Zauważyć trzeba, że działanie $\mathrm{w}$ imieniu lub $\mathrm{w}$ interesie podmiotu zbiorowego, bądź niedopełnienie obowiązków określonej osoby fizycznej, jest relacjonowane w stosunku do uprawnień lub pełnomocnictwa mającego umocowanie prawne, jak też będzie wymagało co najmniej możliwości przyniesienia korzyści podmiotowi zbiorowemu. Istotne jest również to, że - w ocenie ustawodawcy - zachowaniem osoby fizycznej, które mogło przynieść podmiotowi zbiorowemu korzyść, jest zarówno dokonanie przestępstwa, za które taki podmiot ponosi odpowiedzialność, ale także usiłowanie przestępstwa, które potencjalnie mogło przynieść takiemu podmiotowi korzyść. Ustawodawca nie wprowadza także żadnych ograniczeń, gdy chodzi o popełnienie czynu zabronionego przez osobę fizyczną w postaci współsprawstwa, sprawstwa kierowniczego, sprawstwa polecającego, podżegania oraz pomocnictwa ${ }^{33}$.

Na brak zgodności polskiej regulacji w zakresie odpowiedzialności podmiotów zbiorowych z decyzja ramową zwraca uwagę C. Nowak, zob. Komentarz do decyzji ramowej Rady UE w sprawie zwalczania korupcji w sektorze prywatnym z dnia 22 lipca 2003 r. (2003/568/WSiSW), (w:) E. Zielińska (red.), Prawo Wspólnot Europejskich a prawo polskie. Dokumenty karne, Warszawa 2005, s. 449-453.

33 Por. B. Nita, Materialnoprawne i procesowe założenia ustawy o odpowiedzialności podmiotów zbiorowych za czyny zabronione pod groźbą kar, Radca Prawny 2003, nr 5, s. 38 i n; J. Potulski, J. Warylewski, Ustawa o odpowiedzialności podmiotów zbiorowych za czyny zabronione pod groźbą kary. Komentarz, Warszawa 2004, s. 33; D. Habrat, Materialnoprawne aspekty odpowiedzialności podmiotów zbiorowych..., s. 89. 
Dodatkową przesłanką pociągnięcia podmiotu zbiorowego jest - co najmniej możliwość przyniesienia podmiotowi zbiorowemu korzyści, chociażby niemajątkowej. Zwrot „chociażby” wskazuje, że ustawodawca objął treścią art. 3 u.o.p.z. każdą korzyść, tj. majątkową i niemajątkową. O ile pojęcie korzyści majątkowej nie nastręcza trudności, bowiem obejmuje każde przysporzenie w majątku podmiotu zbiorowego postaci zwiększenia aktywów lub zmniejszenia pasywów, o tyle trudnym do uchwycenia jest zakres pojęcia „korzyści niemajątkowej” w przypadku podmiotu zbiorowego. Nie przekonują stwierdzenia w doktrynie, że pod tym rodzajem korzyści należy rozumieć „korzyść, która nie jest przeliczalna na pieniądze” ${ }^{34}$. Trzeba też zauważyć, że niekiedy granica między korzyścią majątkową a inną nie zawsze będzie łatwa do określenia w praktyce i często dwa zbiory, w których można by pogrupować korzyść majątkową i niemajątkową będą miały część wspólną. Dla przykładu można podać zachowania zmierzające do zdobycia przychylności kontrahentów, informacji gospodarczej o produkcie czy zawieranych umowach bądź informacji objętych tajemnicą przedsiębiorstwa. Choć powyższe korzyści nie mają materialnego charakteru, to w sferze obrotu gospodarczego dość szybko mogą przełożyć się na korzyść majątkową 35 .

Druga przesłanka warunkująca odpowiedzialność podmiotu zbiorowego, także za przestępstwa korupcyjne, została uregulowana w art. 4 u.o.p.z. Przepis ten stanowi, że podmiot zbiorowy podlega odpowiedzialności, jeżeli fakt popełnienia czynu zabronionego przez osobę fizyczną, o której mowa w art. 3 u.o.p.z., został potwierdzony prawomocnym:

a) wyrokiem skazującym tę osobę,

b) wyrokiem warunkowo umarzającym wobec niej postępowanie karne albo postępowanie w sprawie o przestępstwo skarbowe,

c) orzeczeniem o udzielenie tej osobie zezwolenia na dobrowolne poddanie się odpowiedzialności, albo

d) orzeczeniem sądu o umorzeniu przeciwko niej postępowania z powodu okoliczności wyłączającej ukaranie sprawcy.

W taki oto sposób ustawodawca uzależnił odpowiedzialność podmiotu zbiorowego od odpowiedzialności osoby fizycznej. Konieczność oczekiwania na wydanie orzeczenia wobec osoby fizycznej, nie tylko związanej z przełamaniem zasady domniemania niewinności ( $\mathrm{tj}$. prawomocnego wyroku skazującego, wyroku nakazowego, wyroku warunkowo umarzającego postępowanie karne oraz prawomoc-

\footnotetext{
34 H. Swarczyński, Odpowiedzialność podmiotów zbiorowych jako nowy rodzaj odpowiedzialności za czyny zabronione pod groźba kary, Palestra 2004, nr 1-2, s. 84 i n.

35 Z. Kwaśniewski, (w:) M. Filar (red.), Z. Kwaśniewski, D. Kala, Komentarz do ustawy o odpowiedzialności podmiotów..., s. 50 .
} 
nego orzeczenia o zezwoleniu na dobrowolne poddanie się odpowiedzialności), ale również orzeczenia, które nie wiążą się z obaleniem domniemania niewinności (tj. orzeczenia o umorzeniu postępowania z powodu okoliczności wyłączającej ukaranie sprawcy). Słusznie przyjęta konstrukcja wtórnej odpowiedzialności podmiotów zbiorowych została poddana krytyce. W piśmiennictwie zwrócono uwagę, że oczekiwanie na prawomocne zakończenie postępowania karnego wobec osoby minimalizuje szanse faktycznego doprowadzenia do ukarania podmiotu zbiorowego. Równocześnie stanowi swoiste zaprzeczenie argumentów leżących u podłoża genezy koncepcji odpowiedzialności podmiotów zbiorowych, wśród których wskazywano trudności w możliwości ustalenia indywidualnego sprawcy powiązanego z podmiotem zbiorowym ${ }^{36}$. Były one widoczne w przypadku dużych podmiotów zbiorowych, o złożonej strukturze wewnętrznej, co rodziło problemy ze spersonifikowaniem osoby (osób) podejmującej określoną decyzję bądź bezpośrednio dopuszczającej się czynu zabronionego. Brak możliwości przypisania określonego zachowania przestępnego osobie fizycznej, działającej w ramach podmiotu zbiorowego, skutkowało przyjęciem założenia o pociągnięciu do odpowiedzialności podmiotu zbiorowego.

Abstrahując od dalszych wątpliwości co do wtórnego charakteru odpowiedzialności podmiotów zbiorowych, przejść należy do trzeciej przesłanki (kumulatywnej). Zgodnie z art. 5 u.o.p.z. podmiot zbiorowy podlega odpowiedzialności, jeżeli do popełnienia czynu zabronionego doszło w następstwie co najmniej:

a) braku należytej staranności w wyborze osoby fizycznej, o której mowa w art. 3 pkt 2 lub 3 u.o.p.z., lub

b) braku należytego nadzoru nad tą osobą - ze strony organu lub przedstawiciela podmiotu zbiorowego.

Przepis ten określa zawinienie podmiotu, które jest niezbędne do pociągnięcia do odpowiedzialności podmiotu zbiorowego. Wina, o której mowa w art. 5 u.o.p.z., czy to w postaci winy w wyborze czy też w postaci winy w nadzorze, powinna zostać stwierdzona na moment popełnienia czynu zabronionego przez sprawcę - osobę fizyczną. Wszelkie nieprawidłowości, jakie miały miejsce wcześniej czy też później,

36 Zob. szerzej, M. Pieth, Criminal Responsibility of Legal and Collective Entities. International Developments, (w:) A. Eser, G. Heine and B. Huber (eds.), Criminal Responsibility of Legal and Collective Entities, Freiburg i. Br. 1999, s. 113-117; C. Wells, Developments in Corporate Liability in England and Wales and a New Offence of Corporate Killing - the English Law Commission's Proposals, (w:) A. Eser, G. Heine and B. Huber (eds.), Criminal Responsibility of Legal and Collective Entities, 119-129 s. in.; C. Wells, Corporations and Criminal Responsibility, Oxford 2001, s. 5-12; 63-81; tejże, Corporations: Culture, Risk and Criminal Liability, The Criminal Law Review 1993, s. 551 i n.; A. Ashworth, Principles of Criminal Law, Oxford 2003, s. 114-123; G. Heine, Odpowiedzialność prawnokarna podmiotów zbiorowych w prawie niemieckim, (w:) A. Zoll, A. Eser (red.), Prawo karne a problem zmiany ustroju politycznego, Kraków 1998, s. 407; B. Nita, Postępowanie przeciwko podmiotowi zbiorowemu według ustawy..., s. 69; tejże, Koncepcje odpowiedzialności karnej podmiotów zbiorowych w angloamerykańskim systemie prawnym, Prokuratura i Prawo 2003, nr 2, s. 114-117. 
są irrelewantne dla odpowiedzialności podmiotu zbiorowego ${ }^{37}$. Zauważyć należy, że zdefiniowanie obu powyższych przesłanek może nastąpić przy wykorzystaniu przepisów prawa cywilnego (art. 427 oraz 429 kc.), pamiętając jednak, że cywilnoprawna konstrukcja winy w nadzorze (culpa in custodiendoart, $427 \mathrm{kc}$.) oraz winy w wyborze (culpa in eligendo, art. 429 kc.) opiera się na domniemaniu, wprawdzie wzruszalnym (praesumptio iuris tantum), to jednak w odniesieniu do represyjnej odpowiedzialności podmiotu zbiorowego jest niedopuszczalne ${ }^{38}$. Zatem w sytuacji, gdy ze strony organu lub przedstawiciela podmiotu kolektywnego zachodzić będzie brak należytej staranności w wyborze lub brak należytego nadzoru nad osobą fizyczną, o której mowa w art. 3 pkt 2 lub 3 u.o.p.z., wówczas zaniechanie podmiotu zbiorowego stanie się jedną z przesłanek odpowiedzialności. W ten sposób ustawodawca wprowadził na grunt przepisów u.o.p.z. przesłankę zawinienia (nullum crimen sine culpa). W obowiązującej postaci pozostaje ona $\mathrm{w}$ zgodności z orzecznictwem Trybunału Konstytucyjnego. Warto w tym miejscu nadmienić, że w wyroku z dnia 3 listopada 2004 r. (sygn. akt K 18/03) Trybunał stwierdził, że ,,art. 42 ust. 1 Konstytucji RP nie wyraża wprost zasady winy, jako przesłanki odpowiedzialności karnej, to zarówno z procesowej zasady domniemania niewinności określonej $\mathrm{w}$ art. 42 ust. 3 Konstytucji, jak i z samej istoty odpowiedzialności represyjnej należy wnosić, że nie powinna być ona nakładana na podmioty, które nie mogły uniknąć popełnienia czynu zabronionego, ani też zapobiec popełnieniu czynu zabronionego. Innymi słowy, niedopuszczalne jest stosowanie środków o charakterze represyjnym (penalnym) wobec podmiotu, któremu nie można zarzucić naruszenia prawa, choćby w postaci zaniechania obowiązkowych działań, które mogły zapobiec popełnieniu czynu zabronionego (podk. - M.M., A.S.)". Jednocześnie Trybunał wskazał, że art. 42 ust. 1 Konstytucji RP nie wyraża wprost zasady winy. Zasadę tę można jednak wyprowadzać ,,z użytego w tym przepisie słowa «czyn», przyjmując, że jest to zachowanie (w tym zaniechanie), na które dana osoba miała wpływ, w szczególności mogła go uniknąć, wybierając zachowanie zgodne z prawem. Odpowiada to szeroko rozumianemu pojęciu zachowania zawinionego. Przyjmując, że stosowanie represji dopuszczalne jest tylko jako reakcja na zachowanie zawinione, należy uznać, że kwestionowany przepis niezgodny jest także z art. 42 ust. 1 Konstytucji”"39.

Odrzucenie przez Trybunał Konstytucyjny tzw. winy w organizacji z uwagi na istnienie szerokiego związku przyczynowego między zachowaniem się osoby fizycznej będącej przedsiębiorcą (art. 3 pkt 4 sprzed nowelizacji) a odpowiedzialnością podmiotu zbiorowego zasługuje na akceptację. Trudno budować odpowiedzialność represyjną li tylko na tym, że organizacyjna działalność podmiotu zbioro-

37 A. Bartosiewicz, Przesłanki odpowiedzialności podmiotu zbiorowego - aspekty praktyczne, Przegląd Prawa Handlowego 2004, nr 2,s. 35 i n.

38 B. Namysłowska-Gabrysiak, Ustawa..., s. 125; D. Habrat, Materialnoprawne aspekty odpowiedzialności..., s. 97.

39 Zob. uzasadnienie wyroku TK z 3.11.2004 r., K 18/03, OTK-A 2004, nr 10, poz. 103. 
wego nie zapewnia warunków, w których można byłoby uniknąć popełnienia czynu zabronionego, a mogło je zapewnić zachowanie należytej staranności przez osobę, o której mowa art. 3 pkt 1 i 4 u.o.p.z. ${ }^{40}$. Dlatego też należy stanąć na stanowisku, że odpowiedzialność podmiotu zbiorowego powinna mieć miejsce tylko wówczas, gdy podmiotowi kolektywnemu można zarzucić naruszenie prawa, choćby w postaci zaniechania obowiązkowych działań, które mogły zapobiec popełnieniu czynu zabronionego, przyjęcie zaś czysto obiektywnej odpowiedzialności represyjnej, opartej wyłącznie na fakcie odniesienia przez dany podmiot zbiorowy korzyści (lub na możliwości odniesienia takiej korzyści), wykracza - jak trafnie wskazał Trybunał Konstytucyjny - poza standardy stanowienia prawa represyjnego w państwie prawa.

12. Analizując przepisy u.o.p.z., nie można pominąć problematyki środków represyjnych ujętych w jej przepisach. Na wstępie należy jednak stwierdzić, że o ile przyjęcie określonego modelu odpowiedzialności podmiotów zbiorowych (jednoetapowego lub kaskadowego) jest w pełni zależne od woli ustawodawcy, o tyle wymóg przyjęcia rodzaju sankcji stosowanych wobec podmiotu zbiorowego wynika $\mathrm{z}$ aktów międzynarodowych, którymi jest związana Rzeczpospolita Polska.

Na gruncie u.o.p.z. występują następujące środki represyjne: kara pieniężna (art. 7), przepadek (art. 8), który obejmuje przedmioty pochodzące bezpośrednio lub pośrednio z czynu zabronionego lub które służyły lub były przeznaczone do popełnienia czynu zabronionego, korzyści majątkowe pochodzące chociażby pośrednio z czynu zabronionego oraz równowartość przedmiotów lub korzyści majątkowych pochodzących chociażby pośrednio z czynu zabronionego. Poza tym, w oparciu o art. 9 u.o.p.z. wobec podmiotu zbiorowego można orzec:

1) zakaz promocji lub reklamy prowadzonej działalności, wytwarzanych lub sprzedawanych wyrobów, świadczonych usług lub udzielanych świadczeń;

2) zakaz korzystania $z$ dotacji, subwencji lub innych form wsparcia finansowego środkami publicznymi;

3) zakaz korzystania z pomocy organizacji międzynarodowych, których Rzeczpospolita Polska jest członkiem;

4) zakaz ubiegania się o zamówienia publiczne;

5) zakaz prowadzenia określonej działalności podstawowej lub ubocznej;

W tym miejscu zwrócić należy uwagę na głosy krytyczne co do skreślenia z art. 5 u.o.p.z. jego końcowego fragmentu poświęconego tzw. winie w organizacji. Spowodowało to wyłączenie z zakresu tego uregulowania odpowiedzialności podmiotu zbiorowego za czyny osób fizycznych opisanych w art. 3 ust. 1 u.o.p.z. Zdaniem T. Razowskiego taki zabieg legislacyjny skutkował „oczywistą niewydolność tego aktu prawnego, bowiem w „przepisie art. 3 pkt 1 u.o.p.z. koncentruje się określenie tych osób fizycznych, które z czysto statystycznego punktu widzenia najczęściej mogą odpowiadać za popełnienie któregokolwiek z przestępstw/przestępstw skarbowych enumeratywnie wyszczególnionych w art. 16 u.o.p.z.", zob. T. Razowski, Odpowiedzialność podmiotów zbiorowych po nowelizacji, Prokuratura i Prawo 2006, nr 9, s. 133. 
6) podanie wyroku do publicznej wiadomości.

Pomijając charakterystykę poszczególnych środków represyjnych, należy zauważyć, że za zachowania sprawcze określone w art. 3 ust. 1 Drugiego Protokołu oraz w przepisach Decyzji Ramowej w sprawie zwalczania korupcji w sektorze prywatnym powinna istnieć możliwość orzeczenia wobec podmiotu zbiorowego sankcji efektywnej, proporcjonalnej i odstręczającej, włączając w to karę grzywny lub inną karę pieniężną i ewentualnie inne sankcje, jak w szczególności:

a) odebranie uprawnień do korzystania ze świadczeń lub pomocy publicznej,

b) terminowy lub stały zakaz prowadzenia działalności gospodarczej,

c) oddanie pod nadzór sądu,

d) sądowy nakaz rozwiązania (art. 4 ust. 1 Drugiego Protokołu; art. 6 Decyzji Ramowej).

Spośród wyżej wymienionych czterech środków (poza sankcjami o charakterze pieniężnym) u.o.p.z. przewiduje tylko odebranie uprawnień do korzystania ze świadczeń lub pomocy publicznej ${ }^{41}$. Co zaś się tyczy środka w postaci terminowego lub stałego zakazu prowadzenia działalności gospodarczej, to u.o.p.z. umożliwia stosowanie zakazu prowadzenia określonej działalności podstawowej lub ubocznej tylko na okres od roku do 5 lat (art. 9 ust. 2), przy czym tego zakazu nie orzeka się, jeżeli jego orzeczenie mogłoby doprowadzić do upadłości albo likwidacji podmiotu zbiorowego lub zwolnień, o których mowa w art. 1 ustawy z dnia 13 marca 2003 r. o szczególnych zasadach rozwiązywania z pracownikami stosunków pracy z przyczyn niedotyczących pracowników ${ }^{42}$.

De lege lata polska regulacja dotycząca odpowiedzialności podmiotów zbiorowych nie przewiduje środków w postaci oddania podmiotu zbiorowego pod nadzór sądu oraz tzw. sądowego nakazu rozwiązania. Zasadnym jest zatem w ramach projektowanych gruntownych zmian odpowiedzialności podmiotów zbiorowych w Polsce wprowadzenie możliwości orzekania poza karą pieniężną także m.in. zakazu prowadzenia określonej działalności czy też likwidacji podmiotu zbiorowego ${ }^{43}$.

13. Czas na odniesienie się do problematyki odpowiedzialności podmiotów zbiorowych za przestępstwa korupcyjne na gruncie u.o.p.z. Na wstępie należy zauważyć, że podmiot zbiorowy nie może odpowiadać za wszystkie przestępstwa, lecz jedynie za te, które zostały ujęte katalogu zamkniętym w art. 16 u.o.p.z. Każdorazo-

41 Zob. art. 9 ust. 1 pkt 2 i 3, w których wymienia się następujące zakazy: 1) zakaz korzystania z dotacji, subwencji lub innych form wsparcia finansowego środkami publicznymi oraz 2) zakaz korzystania z pomocy organizacji międzynarodowych, których Rzeczpospolita Polska jest członkiem.

42 Dz.U. Nr 90, poz. 844, Nr 213, poz. 2081 i Nr 223, poz. 2217, z 2004 r. Nr 96, poz. 959 oraz z 2005 r. Nr 62 , poz. 551.

43 W. Wróbel, Odpowiedzialność karna..., s. 8-9; D. Habrat, Materialnoprawne aspekty odpowiedzialności..., s. $150-153$. 
wa zmiana w obrębie katalogu rzutuje na odpowiedzialność podmiotu zbiorowego. Dzieje się tak również w sytuacji modyfikacji poszczególnych typów czynów zabronionych w części szczególnej Kodeksu karnego, Kodeksu karnego skarbowego, jak również w przepisach karnych konstruujących czyny zabronione w ustawach szczególnych (np. ustawa o działalności ubezpieczeniowej, ustawa o obligacjach, ustawa o świadczeniach opieki zdrowotnej finansowanych ze środków publicznych). Powyższa teza wynika z faktu, że regulacja art. 16 u.o.p.z. odwołuje się li tylko do konkretnych przepisów, nie zaś do wyraźnie wskazanych znamion czynów zabronionych. Ponadto, wskazany enumeratywnie krąg przestępstw, za które może odpowiadać podmiot zbiorowy, nie łączy się z jakimikolwiek restrykcjami w zakresie form współdziałania przestępnego lub postaci stadialnych tych czynów. Ważne, aby były to czyny zabronione. zamieszczone w katalogu, wyczerpujące zarazem znamiona danej postaci zjawiskowej bądź stadialnej przestępstwa oraz skutkujące dla podmiotu zbiorowego jakąkolwiek korzyścią bądź możliwością odniesienia takiej korzyści, jak też nastąpiło spełnienie pozostałych przesłanek wskazanych w art. 4 i 5 u.o.p.z.

Wśród bezładnie ujętego katalogu zamkniętego w art. 16 ust. 1 u.o.p.z. mowa jest także o możliwości odpowiedzialności podmiotu zbiorowego, jeżeli osoba fizyczna, wskazana w art. 3 ustawy, popełniła przestępstwo łapownictwa i płatnej protekcji, określone w przepisach art. 228-230a, art. 250a, art. 296a i art. 296b Kodeksu karnego oraz art. 192b i art. 192c ustawy z dnia 27 sierpnia 2004 r. o świadczeniach opieki zdrowotnej finansowanych ze środków publicznych ${ }^{44}$. Pokrótce odnosząc się do poszczególnych czynów zabronionych, stwierdzić należy, że podmiot

Dz.U. Nr 210, poz. 2135, z późn. zm. Przepis art. 192b ust. 1 stanowi „Kto, prowadząc obrót lekami lub wyrobami medycznymi albo świadcząc usługi farmaceutyczne, albo posiadając upoważnienie do wystawiania recept na leki podlegające refundacji ze środków publicznych lub mając, z racji zajmowanego stanowiska lub pełnionej funkcji, istotny wpływ na podejmowanie decyzji związanych z zaopatrzeniem świadczeniodawcy w leki lub wyroby medyczne, żąda lub przyjmuje nieuzasadnioną korzyść majątkową dla siebie lub osoby trzeciej, albo jej obietnicę w zamian za wykonanie lub powstrzymanie się od wykonania obowiązku służbowego, które prowadzi do nieuzasadnionego wzrostu poziomu sprzedaży leków lub wyrobów medycznych podlegających refundacji ze środków publicznych, podlega karze pozbawienia wolności od 3 miesięcy do lat 5 ". Ustęp 2 wskazuje, że tej samej karze podlega, kto w przypadkach określonych w ust. 1 oferuje, udziela lub obiecuje udzielić korzyści majątkowej. W przypadku mniejszej wagi sprawca czynu określonego w ust. 1 lub 2 podlega grzywnie, karze ograniczenia wolności albo pozbawienia wolności do lat 2 (ust. 3). Natomiast ust. 4 przewiduje klauzulę niepodlegania karze mówiąca, że „Nie podlega karze sprawca przestępstwa określonego w ust. 2 albo 3 w związku z ust. 2, jeżeli korzyść majątkowa albo jej obietnica zostały przyjęte, a sprawca zawiadomił o tym fakcie organ powołany do ścigania przestępstw i ujawnił wszystkie istotne okoliczności przestępstwa, zanim organ ten o nim się dowiedział.” Z kolei przepis art. 192c powyższej ustawy stwierdza, że „1. Kto zajmując się wytwarzaniem lub obrotem lekami lub wyrobami medycznymi podlegającymi refundacji ze środków publicznych różnicuje ceny tych leków i wyrobów medycznych w umowach z hurtowniami farmaceutycznymi, w tym także stosuje uciążliwe lub niejednolite warunki tych umów lub uzależnia zawarcie umowy od przyjęcia lub spełnienia przez hurtownię farmaceutyczną innego świadczenia, niemającego rzeczowego ani zwyczajowego związku z przedmiotem umowy, podlega karze pozbawienia wolności od 3 miesięcy do lat 5. 2. Tej samej karze podlega, kto w wypadkach określonych w ust. 1 oferuje, udziela lub obiecuje udzielić korzyści majątkowej. 3. W przypadku mniejszej wagi sprawca czynu określonego w ust. 1 lub 2 podlega grzywnie, karze ograniczenia wolności albo pozbawienia wolności do lat 2. 4. Nie podlega karze sprawca przestępstwa określonego w ust. 2 albo 3 w związku z ust. 2, jeżeli korzyść majątkowa albo jej obietnica zostały przyjęte, a sprawca zawiadomił o tym fakcie organ powołany do ścigania przestępstw i ujawnił wszystkie istotne okoliczności przestępstwa, zanim organ ten o nim się dowiedział". 
zbiorowy może ponosić odpowiedzialność za przestępstwo sprzedajności (art. 228 kk.), w szczególności, gdy osoba w związku z pełnieniem funkcji publicznej, przyjmuje korzyść majątkową lub osobistą albo jej obietnicę za zachowanie stanowiące naruszenie przepisów prawa ( $\$ 3$, ewentualnie $\S 5$, gdy nastąpi przyjęcie korzyści majątkowej znacznej wartości albo jej obietnicy) lub w związku z pełnieniem funkcji publicznej uzależnia wykonanie czynności służbowej od otrzymania korzyści majątkowej lub osobistej albo jej obietnicy lub takiej korzyści żąda (§ 5).

Podmiot zbiorowy może także ponosić odpowiedzialność za przekupstwo (łapownictwo czynne), tzw. „płatną protekcję” (art. $230 \mathrm{kk}$.) oraz tzw. „,czynną płatną protekcję" (art. 230a kk.), i co do zasady nie ma wątpliwości w tym zakresie. Warto jednak zastanowić się nad pytaniem, czy podmiot zbiorowy poniesie odpowiedzialność karną, gdy zaistnieje sytuacja określona w przepisie art. 229 § 6 kk., tj. gdy sprawca przestępstwa przekupstwa określonego w art. 229 § 1-5 kk. powiadomił organ powołany do ścigania przestępstw o fakcie przyjęcia korzyści majątkowej lub osobistej albo ich obietnicy przez osobę pełniącą funkcję publiczną, i ujawnił wszystkie istotne okoliczności przestępstwa, zanim organ ten o nim się dowiedział. Zbieżne pytanie można odnieść do sprawcy tzw. czynnej płatnej protekcji (art. 230a $\S 3 \mathrm{kk}$.), gdy dokonał samodenuncjacji przed organem ścigania i ujawnił wszystkie istotne okoliczności przestępstwa, zanim organ ten o nim się dowiedział. W obu przypadkach nie jest możliwe ściganie osoby fizycznej z uwagi na ustawowe klauzule niepodlegania karze, które notabene pozostają w sprzeczności z regulacjami Konwencji NZ, Konwencji przeciwko korupcji, Konwencji OECD o zwalczaniu przekupstwa zagranicznych funkcjonariuszy publicznych w międzynarodowych transakcjach handlowych, Prawnokarnej konwencji o korupcji Rady Europy oraz aktami prawnymi Unii Europejskiej ${ }^{45}$.

Prima facie odmiennie sytuacja wygląda, gdy chodzi o podmiot zbiorowy. Przepis art. 4 u.o.p.z. m.in. wskazuje na możliwość odpowiedzialności podmiotu kolektywnego, gdy zapadło orzeczenie o umorzeniu postępowania przeciwko osobie fizycznej, o której mowa w art. 3, z powodu okoliczności „wyłączającej ukaranie sprawcy". Zwrot ten nie jest zdefiniowany w ustawodawstwie polskim, zaś w piśmiennictwie istnieją wątpliwości co do znaczenia tego pojęcia ${ }^{46}$. Spory doktrynalne nie dotyczą jednak objęcia tym terminem ustawowych klauzul niekaralności. Ich wystąpienie - zgodnie z przepisem art. $17 \S 1$ pkt $4 \mathrm{kpk}$. - prowadzi do odmowy wszczęcia postępowania karnego, bądź umorzenia postępowania już wszczętego. Wydawałoby się zatem, że pomimo wystąpienia negatywnej przesłanki procesowej, w przypadku procedowania wobec osoby fizycznej, dopuszczalnym staje się odpo-

45 Zob. szerzej M. Melezini, A. Sakowicz, Nowe regulacje antykorupcyjne a standardy międzynarodowe..., s. 279230 oraz podana tam literatura.

46 Por. Z. Ćwiąkalski, (w:) A. Zoll (red.), G. Bogdan, K. Buchała, Z. Ćwiąkalski, M. Dąbrowska-Kardas, P. Kardas, J. Majewski, M. Rodzynkiewicz, M. Szewczyk, W. Wróbel, Kodeks karny. Część ogólna. Komentarz do art. 1-116 kk., Kraków 2004, s. 1302-1305. 
wiedzialność podmiotu zbiorowego. Sprawa nie jest tak oczywista, bowiem ustawodawca dopuścił odpowiedzialność podmiotu zbiorowego tylko w sytuacji, gdy orzeczenie o umorzeniu postępowania przeciwko osobie fizycznej, o której mowa w art. 3 u.o.p.z., z powodu okoliczności wyłączającej ukaranie sprawcy, zostanie wydane tylko przez „sąd”, choć w praktyce większość takich postanowień wydaje organ postępowania przygotowawczego. $Z$ powyższego płynie wniosek trudny do zaakceptowania z punktu konstytucyjnej zasady równości, jak również ze względów politycznokryminalnych. Oto bowiem w przypadku „sądowego" umorzenia postępowania wobec osoby fizycznej, o której mowa w art. 3 u.o.p.z., z powodu np. niepodlegania karze, będzie możliwe procedowanie i ewentualne skazanie podmiotu zbiorowego, zaś w sytuacji umorzenia postanowienia przez prokuratora, pociągnięcie do odpowiedzialności podmiotu kolektywnego staje się niedopuszczalne.

Podmiot zbiorowy może również ponosić odpowiedzialność za przestępstwo korupcji wyborczej (art. 250a), tzw. korupcji prywatnej (art. 296a kk.) oraz tzw. korupcji w sporcie (art. 296b kk.).

W tym miejscu należy zwrócić uwagę na ostatnią zmianę ${ }^{47}$ w treści art. 296a kk., która poszerzyła pole kryminalizacji, co nie pozostało bez wpływu na odpowiedzialność podmiotu zbiorowego. Nowe brzmienie art. 296a § 1 kk. przewiduje odpowiedzialność karną za sprzedajność w sektorze prywatnym osoby, która „pełniąc funkcję kierowniczą w jednostce organizacyjnej wykonującej działalność gospodarczą lub pozostając $\mathrm{z}$ nią w stosunku pracy, umowy zlecenia lub umowy o dzieło, żąda lub przyjmuje korzyść majątkową lub osobistą albo jej obietnicę, w zamian za nadużycie udzielonych mu uprawnień lub niedopełnienie ciążącego na nim obowiązku mogące wyrządzić tej jednostce szkodę majątkową albo stanowiące czyn nieuczciwej konkurencji lub niedopuszczalną czynność preferencyjną na rzecz nabywcy lub odbiorcy towaru, usługi lub świadczenia”. Przytoczona treść art. 296a § 1 kk. wskazuje, że jest to przestępstwo ogólnosprawcze. Przemawia za tym zwrot „kto, pełniąc funkcję kierowniczą w jednostce organizacyjnej wykonującej działalność gospodarczą lub pozostając z nią w stosunku pracy, umowy zlecenia lub umowy o dzieło". Ponadto, w nowym brzmieniu art. 296a $§ 1 \mathrm{kk}$. dyspozycją przepisu zostało objęte zachowanie polegające na ,żądaniu” korzyści. Są to zmiany pozytywne. Nie pozwalają jednak na wyrażenie tezy, że nowe brzmienie art. 296a § $1 \mathrm{kk}$. w pełni realizuje zobowiązanie konwencyjne (art. 8 Konwencji Rady Europy o korupcji) oraz czyni zadość Decyzji Ramowej w sprawie korupcji w sektorze prywatnym.

Po pierwsze, przepis art. 296a $\S 1 \mathrm{kk}$. po zmianie uczynionej nowelą z dnia 24 października 2008 r. wymaga, by żądanie korzyści, otrzymanie korzyści lub jej obietnicy było powiązane: 
a) z zachowaniem mogącym wyrządzić jednostce szkodę majątkową,

b) z czynem nieuczciwej konkurencji lub

c) z niedopuszczalną czynnością preferencyjną na rzecz nabywcy lub odbiorcy towaru, usługi lub świadczenia.

Można rzec, że z punktu widzenia art. 2 ust. 1 lit. b) Decyzji Ramowej w sprawie korupcji w sektorze prywatnym jest to rozwiązanie możliwe do zaakceptowania, ponieważ państwa członkowskie mogą ograniczyć zakres zastosowania tej regulacji li tylko do działań, które oznaczają lub mogą oznaczać zakłócenie konkurencji w odniesieniu do kupna towarów lub usług (art. 2 ust. 3). Wątpliwość powstaje, gdy nastąpi odwołanie do art. 7 Konwencji Rady Europy oraz art. 21 Konwencji NZ, bowiem obie te regulacje nie przewidują możliwości takiego ograniczenia zakresu przedmiotowego tych przepisów. Wskazują, że chodzi w tych przepisach o każde działanie lub zaniechanie, które powoduje naruszenie obowiązków. Wydaje się więc, że zasadnym byłoby całkowite uniezależnienie odpowiedzialności karnej za przestępstwo korupcji w sektorze prywatnym od zmaterializowania się jednego z powyższych trzech warunków ${ }^{48}$.

Po drugie, regulacja art. 296a $§ 1$ kk. wiąże się z objęciem jego zakresem jedynie zachowań sprawczych w sferze gospodarczej. Oznacza to, że poza treścią tego przepisu pozostają zachowania o charakterze korupcyjnym w ramach działalności społecznej bądź o charakterze non-profit. Nie jest to do pogodzenia z treścią decyzji ramowej w sprawie korupcji w sektorze prywatnym oraz Konwencji Rady Europy ${ }^{49}$. W obu aktach prawnych (art. 1 decyzji ramowej oraz art. 1 d) Konwencji Rady Europy) wskazują, że termin „osoba prawna” oznacza jakikolwiek podmiot mający taki status na podstawie właściwego prawa wewnętrznego danego państwa, z wyłączeniem państw i innych instytucji państwowych wykonujących władcze uprawnienia państwa oraz publicznych organizacji międzynarodowych. Wydaje się, że czyniąc zadość regulacjom międzynarodowym (europejskim) oraz dążąc do spójnej polityki antykorupcyjnej, należałoby objąć zakresem art. 296a $\$ 1$ kk. zachowania sprawcze o charakterze korupcyjnym osób fizycznych powiązanych z wszelkimi podmiotami (w tym np. fundacjami oraz stowarzyszeniami) posiadającymi osobowość prawną lub tzw. ułomną osobowość prawną. Pozwoliłoby to nie tylko na kompleksowe zwalczanie przestępczości korupcyjnej przez osoby fizyczne oraz osoby prawne.

Zob. szerzej, M. Melezini, A. Sakowicz, Korupcja prywatna w polskim prawie karnym w ujęciu międzynarodowym i prawno porównawczym, (w:) P.J. Suwaj, D.R. Kijowski, Patologie w administracji publicznej, Warszawa 2009, s. 309-312 oraz podana tam literatura.

49 Uwaga ta nie dotyczy art. 21 Konwencji NZ, który przewiduje fakultatywne rozwiąanie w zakresie korupcji w sektorze prywatnym, odnoszące się jedynie do zachowań sprawczych w ramach „działalności gospodarczej, finansowej lub komercyjnej". 


\section{SUMMARY}

The classical concept of criminal liability, involving the imposition of a penalty for the culpable commission of a prohibited act, perceived such liability as being applicable only in respect of natural persons. The situation was, and is, different as regards civil liability, whose essence is constituted by the obligation to compensate for damage caused by the obliged person or another person: such liability may apply to both natural and legal persons. The contemporary legal systems of some countries also envisage the imposition of criminal liability as regards certain legal persons and similar organisational entities - either within criminal codifications or on the basis of different statutes.

This paper attempts to present the problems involved with the concepts of corporate criminal liability, followed by an analysis of the approaches taken by different international documents (e.g. Council of Europe Criminal Law Convention on Corruption (1998) with additional Protocol (2005), Convention on the Fight against Corruption involving Officials of the Member States of the EU (1997) as well a Framework Decision on Corruption in the Private Sector (2003), but also in Poland -on the basis of the Collective Entities' Liability for Prohibited Acts Subject to Penalty Act 2002.

The next part will focus on the liability of a collective entity for corruption offences listed in Article 16 of the Act. It is derivative in nature, being related to the criminal liability of a natural person linked to this entity. The fact that a natural person has committed a punishable act still must be confirmed by one of the final judicial decisions or prosecutor's decisions mentioned in Article 4. 